\title{
LIFE INSURANCE
} AND THE

\section{DEMOGRATIC STATE}

B Y

\author{
M. ALBERT LINTON \\ PRESIDENT, PROVIDENT MUTUAL LIFE \\ INSURANCE COMPANY OF PHILADELPHIA
}

\author{
$\diamond$ \\ THE BARBARA WEINSTOCK LECTURE ON THE MORALS OF TRADE \\ DELIVERED AT THE \\ UNIVERSITY OF CALIFORNIA, BERKELEY \\ APRIL 22, 1941
}

UNIVERSITY OF CALIFORNIA PRESS B ERKELEY A N L OS ANGELES, 1941 


\section{UNIVERSITY OF CALIFORNIA PRESS}

BERKELEY, CALIFORNIA

\section{CAMBRIDGE UNIVERSITY PRESS}

LONDON, ENGLAND

COPYR1GHT, I94I, BY

THE REGENTS OF THE UNIVERITY OF CALIFORNTA

PRINTED IN THE UNITED STATES OF AMERICA 